\title{
PENERAPAN MODEL ROLE PLAYING UNTUK MENINGKATKAN HASIL BELAJAR IPS POKOK BAHASAN PENGARUH KEGIATAN EKONOMI SISWA KELAS V SDN 7 PATOKAN KECAMATAN SITUBONDO KABUPATEN SITUBONDO
}

\author{
Aenor Rofek ${ }^{1}$ \\ ${ }^{1}$ Universitas Abdurachman Saleh \\ Corresponding Email: gonzalesrofik99@gmail.com
}

Received: Nov 2, $2020 \quad$ Revised: Nov 10, $2020 \quad$ Accepted: Nov 12, 2020

\begin{abstract}
ABSTRAK
Pembelajaran IPS di SDN 7 Patokan mengalami kendala, Materi IPS sendiri adalah ilmu pasti dan kompleks. IPS tidak hanya mempelajari sejarah akan tetapi semua aspek sosial yang menjadi objek yang luas. Mata pelajaran IPS dalam hal ini sering kali dianggap materi yang susahsusah gampang hal ini dikarekan objek permasalahan atau keilmuannya hanya berkaitan dengan masyarakat ataupun kegiatan ekonomi. Masalah pembelajaran kebanyakan siswa masih bingung dan masih kesulitan dalam pemahaman, hal ini disebabkan kurang menariknya guru dalam pembelajaran dalam proses belajar mengajar, karena ketidaksiapan guru menggunakan metode yang sangat terbatas. Dengan metode Role playing diharapkan dapat meningkatkan hasil belajar siswa khususnya materi IPS dikarenan role playing dianggap sebagai alternative solusi penyelesaian dari masalah di bidang social berkaitan dengan komunikasi atau kekompakan. Sehingga penggunaan Role playing sebagai solusi pada penelitian ini Hal tersebut sangat berdampak terhadap hasil belajar siswa pada mata pelajaran IPS. pada siklus I dan siklus II tersebut dapat diketahui bahwa bahwa materi IPS pengaruh ekonomi terdapat peningkatan. Hal ini dibuktikan bahwa hasil penelitian pada prasiklus sebesar $32 \%$, siklus I sebesar $60 \%$, dan siklus II sebesar $84 \%$. Peningkatan ini terjadi karena adanya penyampaian meteri yang jelas dan pemberian dorongan yang kuat serta metode pembelajaran yang menarik dari guru.

Kata Kunci: Role Playing, peningkatan, IPS, dan Ekonomi.
\end{abstract}

\begin{abstract}
Social studies learning at SDN 7 Benchmarks has encountered obstacles. Social studies material itself is an exact and complex science. IPS does not only study history but all social aspects which become its broad object. Social studies subjects in this case are often considered difficult-toeasy material, this is because the object of the problem or science is only related to society or economic activities. The learning problems of most students are still confused and still have difficulty understanding, this is due to the lack of attractiveness of the teacher in learning in the teaching and learning process, because the teacher is not prepared to use very limited methods. With
\end{abstract}


the Role playing method it is expected to improve student learning outcomes, especially social studies material because role playing is considered an alternative solution to solving problems in the social field related to communication or cohesiveness. So that the use of role playing as a solution in this study has a profound impact on student learning outcomes in social studies subjects. In cycle I and cycle II, it can be seen that the social impact of social studies material has increased. This is proven by the results of research in pre-cycle by $32 \%$, cycle I by $60 \%$, and cycle II by $84 \%$. This increase occurred because of the clear delivery of materials and the provision of strong encouragement and attractive learning methods from the teacher.

Keywords: Role Playing, improvement, Social Studies, and Economy.

\section{A. Latar Belakang}

Perubahan kurikulum di Indonesia membuat guru semakin dituntut untuk selalu berperan aktif dalam mengembangkan pengajaran. Sekolah dasar menjadi tempat pijakan awal bagi seorang anak didik untuk belajar memahami. Sekolah dasar merupakan salah satu lembaga pendidikan formal yang mempelajari apa itu IPS, apa itu pengetahuan alam dan sebagainya. Penanaman konsep awal yang salah akan mempengaruhi perkembangan minat serta motivasi anak didik dalam menapaki jenjang pendidikan yang lebih tinggi.

Sejauh ini pendidikan di Indonesia masih didominasi oleh pandangan bahwa pengetahuan sebagai perangkat fakta-fakta yang harus dihapal. Pembelajaran masih terfokus pada guru sebagai sumber utama pengetahuan, kemudian metode ceramah menjadi pilihan utama dalam menentukan strategi belajar. Sehingga konsep dasar matematika tidak dapat diterima dengan baik oleh siswa. siswa.

Pada umumnya, faktor rendahnya tingkat keberhasilan dalam pembelajaran disebabkan oleh faktor dari siswa itu sendiri, faktor dari guru, tidak adanya media pembelajaran yang digunakan, serta penggunaan metode pembelajaran yang kurang tepat. Jika hal ini dibiarkan, maka tidak menutup kemungkinan akan timbul rendahnya minat, motivasi, dan kemampuan siswa terhadap pelajaran matematika.

Materi IPS sendiri adalah ilmu pasti dan kompleks. IPS tidak hanya mempelajari sejarah akan tetapi semua aspek sosial yang menjadi objek yang luas. Mata pelajaran IPS dalam hal ini sering kali dianggap materi yang susah-susah gampang hal ini dikarekan objek permasalahan atau keilmuannya hanya berkaitan dengan masyarakat ataupun kegiatan ekonomi. Pemikiran yang cenderung menyepelekan inilah yang terkadang membuat siswa lalai dalam belajar. 
Mengetahui kekhasan IPS dan karakteristik siswa, dapat diupayakan cara-cara yang sesuai dalam pembelajarannya, sehingga tujuan pembelajaran dapat tercapai, baik dari segi kognitif, afektif, maupun psikomotorik. Peranan seorang guru dalam hal ini sangat penting. Guru harus bisa menciptakan pembelajaran yang menarik dan mudah dipahami oleh siswa dengan baik, sehingga pelajaran IPS dapat menjadi mata pelajaran yang serius oleh siswa.

Secara spesifik masalah yang berhasil diidentifikasi dalam pembelajaran IPS di SDN 7 Patokan adalah penentuan penerapan metode dalam pembelajaran, IPS selalu dianggap sebelah mata sehingga banyak yang merasa mudah oleh siswa, akan tetapi ketika pembelajaran kebanyakan siswa masih bingung dan masih kesulitan dalam pemahaman, hal ini disebabkan kurang menariknya guru dalam pembelajaran dalam proses belajar mengajar, karena ketidaksiapan guru menggunakan metode yang sangat terbatas. Hal tersebut sangat berdampak terhadap hasil belajar siswa pada mata pelajaran IPS. Nilai IPS sebagai skor awal peneliti yang diambil dari hasil ulangan pada materi sebelumnya/sebelum tindakan, menunjukkan bahwa persentase hasil belajar siswa masih rendah yaitu $32 \%$ atau hanya 8 siswa dari 25 siswa yang tuntas hasil belajarnya.

Berdasarkan hasil wawancara dengan guru, diketahui bahwa guru menemukan kesulitan dalam pemilihan atau menentukan metode yang akan diterapkan pada saat menyusun RPP. Sehingga, guru sering menerapkan metode ceramah tanpa menggunakan media yang menarik. Guru hanya menjelaskan konsep-konsep perkalian di papan tulis. Hasil wawancara dengan siswa, diketahui bahwa siswa merasa jenuh pada saat pembelajaran. Pada awal pembelajaran siswa sangat antusias untuk belajar. Dengan demikian, dapat diketahui akar masalah atau pokok permasalahan dari rendahnya hasil belajar siswa yaitu selain penerapan metode yang kurang tepat,juga kurangnya penggunaan media pembelajaran sehingga siswa menjadi bosan dan mengalami kesulitan dalam memahami materi.

\section{METODE PENELITIAN}

\section{A. Jenis Penelitian}

Penelitian ini menggunakan rancangan penelian PTK (penelitian tindakan kelas). Hakikat tindakan kelas adalah adanya upaya tindakan yang dilakukan secara terencana dan sistematis untuk memecahkan masalah pembelajaran di kelas yang dihadapi oleh para guru sehari-hari (Sunardi,

2008: 6). Dalam Penelitian ini digunakan model skema penelitian Kemmis \& Mc Taggart, 
menyatakan bahwa model Penelitian berbentuk spiral dengan masing-masing siklus terdiri atas 4 tahap, yaitu perencanaan, tindakan, observasi, dan refleksi (dalam Sunardi, 2008:13-14).

Keempat tahap tersebut dipandang sebagai siklus spiral dan dapat digambarkan sebagai berikut:

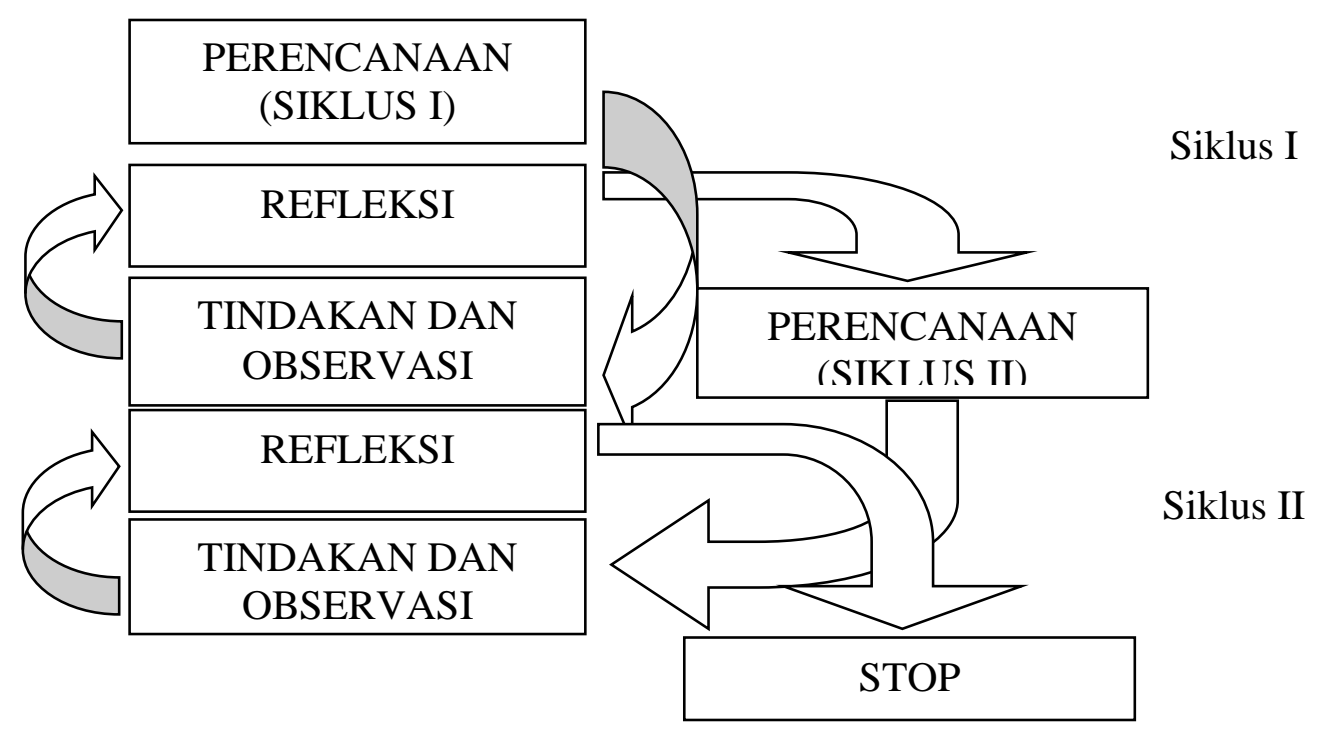

Gambar 3.1 Adaptasi dari model kemmis \& Mc Taggart (dalam Sunardi, 2008:14)

Pendekatan yang digunakan dalam penelitian ini adalah pendekatan kualitatif, yaitu yang digunakan untuk data yang diperoleh dari hasil observasi dan wawancara dengan guru dan siswa. Penelitian ini dilakukan dalam 2 siklus, diawali dengan perencanaan, tindakan, dan observasi, serta refleksi. Jika pada siklus I aktivitas dan ketuntasan belajar sudah tercapai, maka tetap diadakan siklus II dengan tujuan melihat peningkatan aktivitas dan ketuntasan belajar siswa selanjutnya. Ketuntasan belajar klasikal dapat dikatakan tercapai apabila 75\% dari jumlah siswa mencapai nilai KBM.

Pada tindakan pendahuluan, dilakukan beberapa kegiatan sebagai langkah awal penelitian

a. Melakukan wawancara dengan guru kelas V sebelum penerapan pembelajarandi kelas.

b. Observasi pada saat pembelajaran IPS berlangsung untuk mengetahui cara guru mengajar di kelas dan cara belajar siswa.

c. Tes pendahuluan, untuk mengetahui tingkat pemahaman siswa tentang materi pengaruh ekonomi.

d. Menentukan jadwal pelaksanaan penelitian.

\section{B. Waktu Tempat Penelitian, dan Karakteristik Anak}


Penelitian ini dilaksanakan di Kelas V Sekolah Dasar Negeri 7 Patokan Kecamatan Arjasa Kabupaten Situbondo pada semester genap tahun ajaran 2019/2020. Ada beberapa pertimbangan yang mendasari pemilihan tempat penelitian ini adalah:

(1) Peneliti merupakan guru di Sekolah Dasar Negeri 7 Patokan

(2) Belum pernah dilakukan penelitian yang sama di Sekolah Dasar Negeri 7 Patokan. (3) Rendahnya Hasil belajar siswa khususnya mata pelajaran IPS.

Karakteristik Anak penelitian ini adalah Kelas V Sekolah Dasar Negeri 7 Patokan Kecamatan Situbondo Kabupaten Situbondo dengan jumlah siswa kelas V sebanyak 25 siswa yang memiliki kemampuan yang heterogen.

\section{Deskripsi per Siklus}

\section{a. Prasiklus}

Pada tahap prasiklus ini dilakukan pengamatan awal untuk mengetahui permasalahan yang terjadi di dalam kelas. Pada siklus ini guru mengajar dengan menggunakan metode dan media yang biasa digunakan oleh guru yaitu buku paket. Pada akhir pembelajaran guru memberikan tes yang mantinya dijadikan dasar dalam penelitian ini.

Pada tahap ini dilakukan pengamatan awal untuk mengetahui masalah yang ditemukan, kemudian disusun rencana berupa tindakan untuk melakukan perbaikan, peningkatan atau perubahan ke arah yang lebih baik. Tindakan yang dilakukan untuk memecahkan masalah tersebut adalah dengan menggunakan metode Role Playing yang diterapkan pada siklus I dan siklus II.

\section{D.Metode Pengumpulan Data}

Metode pengumpulan data adalah cara yang dapat digunakan untuk mengumpulkan data (Arikunto, 2002:126). Metode yang digunakan dalam penelitian ini adalah: (1) Observasi, (2) Dokumentasi, (3) Wawancara, (4) Tes.

\section{E.Analisis Data}

Analisis data merupakan penentu dalam menyusun dan mengolah data yang dikumpulkan guna mempermudah mendapatkan kesimpulan yang dapat dipertanggung jawabkan. Menurut Arikunto (2000:353), analisis data deskriptif kualitatif adalah memberikan predikat kepada variabel yang diteliti sesuai dengan kondisi yang sebenarnya. Data yang akan dianalasis dalam penelitian ini adalah: 
Persentase ketuntasan hasil belajar siswa, untuk menghitung hailbelajar siswa digunakan rumus sebagai berikut:

$$
\mathrm{E}=\frac{n}{N} \times 100 \%
$$

Keterangan:

$\mathrm{E} \quad=$ Hasilbelajar siswa

$\mathrm{n} \quad=$ Jumlah Skor Yang Diperoleh

$\mathrm{N} \quad=$ Jumlah Skor Maksimal

Sumber: Nurkancana dan Sunartana (1990:94)

Tabel 3.1Kategori Hasil Belajar Siswa

\begin{tabular}{|c|c|}
\hline Presentase & Kategori \\
\hline $\mathrm{P} \geq 90 \%$ & Sangat baik \\
\hline $80 \% \leq \mathrm{P}<90 \%$ & Baik \\
\hline $65 \% \leq \mathrm{P}<80 \%$ & Cukup baik \\
\hline $55 \% \leq \mathrm{P}<65 \%$ & Kurang baik \\
\hline $\mathrm{P}<55 \%$ & Tidak baik \\
\hline
\end{tabular}

Nurkancana dan Sunartana (1990:93)

Kriteria ketuntasan siswa dinyatakan sebagai berikut :

a. Daya serap perorangan, seorang siswa dikatakan tuntas apabila telah mencapai hasil $\geq 65$ dari nilai maksimal 100

b. Daya serap klasikal, suatu kelas dikatakan tuntas apabila terdapat minimal $75 \%$ telah mencapai nilai $\geq 65$. (Depdiknas 2006:19)

\section{HASIL DAN PEMBAHASAN}

\section{A. Hasil kegiatan}

\section{Tindakan Penelitian}

Dalam Tindakan Pemantapan Kemampuan Profesional (PKP) ini menggunakan beberapa tahapan yang meliputi: tahap perencanaan, pelaksanaan tindakan, pengamatan, dan refleksi. Penelitian ini dilaksanakan sebanyak dua siklus, siklus 1 sebagai wujud perbaikan tetapi jika masih ada yang belum tuntas dilakukan siklus 2 sebagai penguatan dari perbaikan kedua.Sedangkan yang diteliti adalah pencapaian peningkatan kecerdasan interpersonal siswa melalui penerapan model pembelajaran role playing. Tahapan pelaksanaan siklus dalam penelitian ini sebagai berikut:

\section{Pra Siklus}

Tahap pra siklus dilakukan untuk mengidentifikasi masalah yang terjadididalam kelas yang mempengaruhi tingkat hasil belajar siswa. Tahap prasiklus meliputi: 
1) Tahap Perencanaan (Planning)

Menyiapkan bahan-bahan yang diperlukan dalam pelaksanaan penelitian, meliputi:

a. Menyiapkan rencana pembelajaran (RPP)

b. Mengecek keseuaian model pembelajaran yang dirumuskan.

2) Tahap Pelaksanaan Kegiatan

Pelaksanaan tindakan ini merupakan pelaksanaan kegiatan pembelajaran yang telah disiapkan sebelumnya. Pelaksanaan tindakan ini meliputi kegiatan sebagai berikut:

a. Guru menyajikan materi IPS pengaruh Ekonomi dengan memberikan gambaran ekonomi masyarakat dan dampak ekonomi yang dimunculkan.

b. Guru bertanya jawab dengan siswa mengenai hal yang belum diketahui siswa.

c. Guru memberikan kesimpulan materi yang disajikan.

3) Tahap Pengamatan (Observasi)

Pada kegiatan observasi peneliti mengobservasi kegiatan belajar mengajar meliputi aktivitas belajar siswa, aktivitas mengajar guru hingga proses evaluasi pembelajaran.

Tabel 4.1 Ketuntasan Hasil Belajar siswa Pra Siklus

\begin{tabular}{|c|c|c|c|c|}
\hline No & $\begin{array}{c}\text { Aspek } \\
\text { Ketuntasan }\end{array}$ & $\begin{array}{c}\text { Jumlah } \\
\text { Siswa }\end{array}$ & $\begin{array}{c}\text { Persentase } \\
\%\end{array}$ & Keterangan \\
\hline 1. & Tuntas & 8 Orang & $32 \%$ & Nilai $>70$ \\
\hline 2. & Belum Tuntas & 17 Orang & $78 \%$ & Nilai $<70$ \\
\hline \multicolumn{2}{|c|}{ Jumlah } & 25 Orang & $100 \%$ & \\
\hline
\end{tabular}

Hasil data siswa yang memperoleh nilai 70 keatas sebanyak 8 orang, dengan persentase 32 $\%$. Hasil tersebut belum mencapai standar ketuntasan belajar secara klasikal, maka dari itu akan dilakukan rencana perbaikan pembelajaran dengan menggunakan metode Role Playing pada pembelajaran IPS bahasan pengaruh ekonomi di Kelas V SDN 7 Patokan Kecamatan Situbondo Kabupaten Situbondo.

4) Tahap Refleksi

Kegiatan pada tahap refleksi adalah mengkaji hal yang telah terjadi selama pelaksanaan tindakan dan observasi berlangsung. Pengkajian kembali digunakan untuk mengetahui jika 
permasalahan yang terjadi pada saat pelaksanaan tindakan observasi. sehingga perlu dilakukan kegiatan pembelajaran selanjutnyadi Siklus I.

\section{Siklus 1}

Pengamatan yang dilakukan pengamat bersama teman sejawat terhadap perilaku belajar siswa pada saat proses pembelajaran. Dalam siklus 1 ini dilaksanakan beberapa proses diantaranya:

\section{Perencanaan}

Langkah perama peneliti menyusun jadwal pelaksanaan tindakan. Jadwal disampaikan pada: Kepala sekolah untuk diketahui dan disetujui, Teman sejawat yang akan membatu dalam pelaksanaan tindakan sebagai observer kepada siswa. Agar siswa siap pada pembelajaran sesuai kompetensi yang akan diajarkan, Langkah kedua peneliti menyusun RPP untuk pelaksanaan tindakan lengkap dengan alat peraga yang diperlukan.

\section{Pelaksanaan Tindakan}

Kegiatan yang akan dilaksanakan dalam tahap pelaksanaan tindakan meliputi:

1. Guru menyiapkan skenario yang akan ditampilkan.

2. Menunjuk beberapa siswa untuk mempelajari skenario dalam waktu beberapa hari sebelum Kegiatan Belajar Mengajar.

3. Guru membentuk kelompok yang anggotanya lima orang (menyesuaikan jumlah siswa)

4. Memberikan penjelasan tentang kompetensi yang ingin dicapai.

5. Memanggil para siswa yang sudah ditunjuk untuk melakonkan skenario yang sudah dipersiapkan.

6. Masing-masing siswa berada di kelompoknya sambil mengamati scenario yang sedang diperagakan.

7. Setelah selesai ditampilkan, masing-masing siswa diberi lembar kerja untuk membahas penampilan yang selesai diperagakan.

8. Masing-masing kelompok menyampaikan hasil kesimpulannya.

9. Guru memberi kesimpulan secara umum.

10. Evaluasi dengan tes.

11. Penutup 
Adapun kegiatan di siklus 1 diberikan tes untuk menguji sejauh mana tingkat keberhasilan daripada pembelajaran dengan menggunakan Role Playing yakni hasil tes evaluasi siklus 1:

Tabel 4.2 Ketuntasan Hasil Belajar siswa Siklus 1

\begin{tabular}{|c|c|c|c|}
\hline Nilai & Jumlah Siswa & Persentase (\%) & $\begin{array}{c}\text { Ketuntasan } \\
\text { Belajar Klasikal }\end{array}$ \\
\hline$>70$ & 15 & $60 \%$ & \multirow{2}{*}{$75 \%$} \\
\hline$<70$ & 10 & $40 \%$ & \\
\hline Jumlah & 25 & $100 \%$ & \\
\hline
\end{tabular}

Data tersebut di distribusikan berdasarkan perolehan hasil evaluasi belajar setiap individu setelah melakukan serangkaian kegiatan belajar melalui pembelajaran dengan menggunakan metode Role Playing.

\section{Observasi}

Peneliti mengamati hasil evaluasi pada akhir pembelajaran, selanjutnya mulai dianalisis dengan menggunakan tabel. Hasil analisis dibandingkan dengan tujuan perbaikan, penelitian dan hasil observasi.

\section{Refleksi}

Peneliti mengamati hasil akhir pelaksanaan tindakan. Jika hasil pelaksanaan tindakan telah sesuai dengan tujuan perbaikan, maka pada tindakan kedua dilakukan pemantapan tindakan pertama untuk lebih meningkatkan prestasi dan meyakinkan ketepatan pelaksanaan tindakan, Tahap Refleksi Terhadap Tindakan:

Kegiatan yang akan dilaksanakan dalam tahap refleksi tindakan meliputi:

a) Guru menganalisis dan menyimpulkan hasil pembelajaran;

b) Guru mencatat kekurangan dalam proses pembelajaran siklus 1 untuk diperbaiki di siklus berikutnya;

c) Guru mencatat kelebihan dalam proses pembelajaran siklus 1 untuk ditingkatkan di siklus-siklus berikutnya (apabila diperlukan)

\section{Siklus 2}

1) Tahap Perencanaan tindakan 
Kegiatan yang akan dilaksanakan dalam tahap perencanaan tindakanmeliputi:

a) Melakukan analisis RPP dan pembelajaran siklus 2 untuk mengetahui kompetensi dasar yang akan disampaikan kepada siswa dalam pembelajaran.

b) Membuat rencana pembelajaran denganmengacu pada tindakan yang diterapkan dalam PKP siklus 2 masih dengan penerapan model pembelajaran Role Playing.

c) Menyiapkan teks petunjuk kerja

d) Menyiapkan naskah/skenario bermain peran;

2) Tahap Pelaksanaan Tindakan

Kegiatan yang akan dilaksanakan dalam tahap pelaksanaan tindakan meliputi:

a) Guru menyiapkan skenario yang akan ditampilkan.

b) Menunjuk beberapasiswa untuk mempelajari skenario dalam waktu beberapa hari sebelum Kegiatan Belajar Mengajar.

c) Guru membentuk kelompok yang anggotanya lima orang (menyesuaikan jumlah siswa)

d) Memberikan penjelasan tentang kompetensi yang ingin dicapai.

e) Memanggil para siswa yang sudah ditunjuk untuk melakonkan scenario tentang kegiatan

f) Masing-masing siswa berada di kelompoknya sambil mengamati skenario yang sedang diperagakan.

g) Setelah selesai ditampilkan, masing-masing siswa diberi lembar kerja untuk membahas penampilan yang selesai diperagakan.

h) Masing-masing kelompok menyampaikan hasil kesimpulannya.

i) Guru memberi kesimpulan secara umum.

j) Evaluasi

k) Penutup

Adapun kegiatan di siklus 2 diberikan tes untuk menguji sejauh mana tingkat keberhasilan daripada pembelajaran dengan menggunakan Role Playing yakni hasil tes evaluasi siklus 2:

Tabel 4.3 Ketuntasan Hasil Belajar siswa Siklus 2

\begin{tabular}{|c|c|c|c|}
\hline Nilai & Jumlah Siswa & Persentase (\%) & $\begin{array}{c}\text { Ketuntasan } \\
\text { Belajar Klasikal }\end{array}$ \\
\hline$>70$ & 21 & $84 \%$ & \\
\hline
\end{tabular}




\begin{tabular}{|c|c|c|}
\hline$<70$ & 4 & $16 \%$ \\
\hline Jumlah & 25 & $100 \%$ \\
\hline
\end{tabular}

Data tersebut di distribusikan berdasarkan perolehan hasil evaluasi belajar setiap individu setelah melakukan serangkaian kegiatan belajar melalui pembelajaran dengan menggunakan metode Role Playing. Di siklus 2 ini adalah kegiatan perbaikan di siklus 1, ada beberapa tindakan yang ditambahkan sehingga siswa yang awalnya masih kurang paham sekarang mulai sudah bisa memahami dan bisa memilah kegiatan yang ekonomi dan yang bukan.

\section{3) Tahap Pengamatan Tindakan}

Kegiatan yang akan dilaksanakan dalam tahap pengamatan tindakan meliputi:

a) Guru mengamati situasi kegiatan belajar mengajar;

b) Guru mengamati aktivitas siswa dalam pembelajaran;

4) Tahap Refleksi Terhadap Tindakan

Kegiatan yang akan dilaksanakan dalam tahap refleksi tindakan meliputi:

a) Guru menganalisis dan menyimpulkan hasil pembelajaran;

b) Guru mencatat kekurangan dalam proses pembelajaran siklus 1 untuk diperbaiki di siklus berikutnya;

c) Guru mencatat kelebihan dan hasil dalam proses pembelajaran siklus 2 untuk ditingkatkan di siklus-siklus berikutnya.

Penelitian ini dianalisis secara deskriftif kualitatif yangterdiridari reduksi pemaparan data dan penyimpulan hasil analisis.

Pengumpulan data dilakukan dalam suatu proses siklus, membandingkan siklus satu dan siklus dua.

5. Hasil prosentase diisikan pada tabel tabulasi kolom.

Indikator pencapaian, keberhasilan ini dapat dilihat dengan adanya perubahan terhadap perkembangan kemampuan anak dalam memahami materi pengaruh ekonomi.Dalam hal ini keberhasilan dalam pembelajaran dapat dilihat dari hasil belajarnya atau menikmati permainan kelompok, dan mampu menyesuaikan dengan lingkungan dan kelompok yang berbeda. Penelitian ini dikatakan berhasil apabila $75 \%$ dari jumlah anak dapat mencapai target keberhasilan. 
Berdasarkan Penelitian yang dilakukan pada siklus Idan siklus II tersebut dapat diketahui bahwa bahwa materi IPS pengaruh ekonomi terdapat peningkatan. Hal ini dibuktikan bahwa hasil penelitian pada prasiklus sebesar $32 \%$, siklus I sebesar 60\%, dan siklus II sebesar $84 \%$. Peningkatan ini terjadi karena adanya penyampaian meteri yang jelas dan pemberian dorongan yang kuat serta metode pembelajaran yang menarik dari guru. Hal ini disebabkan karena waktu yng digunakan guru untuk menyampaikan materi sudah efisien sehingga anak dapat bersosialisasi dan bekerja sama dalam memecahkan masalah secara bersama-sama.

\section{Kesimpulan Dan Saran}

\section{A. Kesimpulan}

Pembelajaran IPS di SDN 7 Patokan mengalami masalah, masalah pembelajaran kebanyakan siswa masih bingung dan masih kesulitan dalam pemahaman, hal ini disebabkan kurang menariknya guru dalam pembelajaran dalam proses belajar mengajar, karena ketidaksiapan guru menggunakan metode yang sangat terbatas. Hal tersebut sangat berdampak terhadap hasil belajar siswa pada mata pelajaran IPS.

pada siklus I dan siklus II tersebut dapat diketahui bahwa bahwa materi IPS pengaruh ekonomi terdapat peningkatan. Hal ini dibuktikan bahwa hasil penelitian pada prasiklus sebesar $32 \%$, siklus I sebesar 60\%, dan siklus II sebesar 84\%. Peningkatan ini terjadi karena adanya penyampaian meteri yang jelas dan pemberian dorongan yang kuat serta metode pembelajaran yang menarik dari guru.

a. bagi guru, berdasarkan hasil penelitian pembelajaran menggunakan metode Role Playing dapat dijadikan alternatif dalam pembelajaran IPS sebagai upaya dalam peningkatan hasil belajar siswa.

b. bagi peneliti lain, Penelitian ini dapat dijadikan sebagai acuan untuk mengadakan penelitian yang sejenis.

\section{Daftar Pustaka}

Hasanto, Radno. 2005. Melatih Anak Berfikir Analisis, Kritis dan Kreatif. Semarang: PT Gramedia Widiasana Indonesia.

Mositoh,dkk. 2006. Strategi Pembelajaran Taman Kanak-kanak. Jakarta: UniversitasTerbuka. 
Mulyasa, H.E. 2009. Praktek Penelitian Tindakan Kelas. Bandung: Rodakarya.

Najlatun,N.\& Galih, W. 2013. Penerapan Teknik Bermain Peran dalam Bimbingan Kelompok untuk Meningkatkan Kemampuan Komunikasi Interpersonal siswa kelas $\mathrm{X}$ Multimedia SMK IKIP Surabaya. Journal Mahasiswa Bimbingan Konseling, 1 (1): 61-78.

Romlah T. 2006. Teori dan Praktik Bimbingan Kelompok. Malang: Universitas Negeri Malang 